\title{
Female Entrepreneurship in Kenya: How do Female Micro-Entrepreneurs Learn to be Entrepreneurial?
}

\author{
Milcah Mulu-Mutuku (Corresponding author) \\ Egerton University, P.O. Box 536, Egerton 20115, Kenya \\ E-mail:mwmilcah@yahoo.com/mmulu@egerton.ac.ke \\ Dolphine Odero-Wanga \\ Egerton University, P.O. Box 536, Egerton 20115, Kenya \\ E-mail: wangadake@yahoo.com/dodero@egerton.ac.ke \\ Adijah Ali-Olubandwa \\ Egerton University, P.O. Box 536, Egerton 20115, Kenya \\ E-mail: olubandwaadijah@yahoo.com
}

Received: December 20, 2014 Accepted: January 10, 2015 Published: March 26, 2015

doi:10.5296/csbm.v2i1.6809ＵRL: http://dx.doi.org/10.5296/csbm.v2i1.6809

\begin{abstract}
There is renewed interest in female entrepreneurship as policy makers recognize the importance of social inclusiveness in economic development. Women's involvement in entrepreneurship is applauded as a necessary precursor to economic growth of developing nations despite women under-representation among business owners. Many factors have been blamed for this under-representation among them, socialisation and lack of motivation in choosing entrepreneurship as a career option. In Kenya, women entrepreneurs have low levels of education; are in need of business knowledge and skills yet unable to pay for business development services; and are affected strongly by patriarchal structures especially the role of husbands. Yet, some few women own growing businesses that contribute towards wealth and employment creation. This study sought to determine how women learn to be entrepreneurial and to establish hindrances to female entrepreneurial learning process. A survey was conducted on 106 women micro-entrepreneurs in the Kenyan dairy processing industry. Data were collected using semi-structured interviews and analysed using descriptive
\end{abstract}




\section{Macrothink}

Case Studies in Business and Management

ISSN 2333-3324 2015, Vol. 2, No. 1

statistics. Findings showed that majority (76.9\%) of the micro-entrepreneurs went into business without any prior business skills. Only 5.5\% of them had training in business-related fields before starting their businesses. Another $17.6 \%$ had learnt some business skills from previous employment. Social contacts and relations were important sources of business knowledge and skills for $68.7 \%$ of them. Rarely did the respondents engage in active search of business knowledge and skills. Probably an entrepreneurship development curriculum weaved through the entire school syllabus would help in entrenching an enterprising culture among women.

Keywords: dairy processing microenterprises, entrepreneurial learning, female entrepreneurship, female micro-entrepreneurs 


\section{Introduction}

For third world countries to realise sustainable development, strategies used must involve the poor who are the majority in developing countries (Institute of Economic Affairs (IEA)/Society for International Development (SID), 2001). One such strategy is entrepreneurship development (Akola \& Heinonen, 2006) especially the development of micro-enterprises (enterprises employing less than 10 persons) since the vast majority of participants in these enterprises, either as enterprise owners or as employees, are the poor (Ondiege, 1995). Attention has therefore been focused on the development of these enterprises as a means of reducing poverty levels and creating employment (Stevenson \& St-Onge, 2005; Akola \& Heinonen, 2006; Palmer, 2008).

Studies have shown that, not all micro-enterprises contribute towards poverty reduction and employment creation. Many have remained subsistence activities in the informal sector, marred by low productivity and low product quality; often unable to support the owners and their families adequately (Palmer, 2008). In addition, there is high failure of these enterprises with eight out of ten of them failing within their first three years and nine out of ten venture-backed start-ups failing to generate meaningful returns (Feinleib, 2012). Enterprises that contribute significantly towards poverty reduction and wealth creation are those that show evident growth. These are the relatively few enterprises that start up and expand, whose owners are open to change, trying different ways of doing things and methods of production, in other words, exhibiting high entrepreneurial learning ability (Stoner, Freeman, \& Gilbert, 1995).

Entrepreneurial learning orientation has a significant positive impact on enterprise performance (Wang, 2008) implying a significant positive impact on poverty reduction and employment creation through benefits accruing from enterprise growth. Entrepreneurial learning is defined as the process through which an individual learns and acquires the knowledge needed in the entrepreneurial venture and entrepreneurial process (Akola \& Heinonen, 2006). It involves learning to recognize and act on opportunities and interacting socially to initiate, organize and manage entrepreneurial ventures (Rae, 2005). Entrepreneurial learning in organizations occur when employees and others in the organization become learning agents for the organization, developing innovative solutions to the organisation's problems (Wang, 2008; Wang \& Rafiq, 2009). At an individual level, it occurs when entrepreneurs accumulate and organize knowledge and information within and across developmental stages in a firm (Kulmala \& Suoranta, 2005). Each person's learning process, rather than being a collection of disassociated pieces of learning, is seen as strongly co-ordinated, organized and integrated (Rae, 1999). Thus entrepreneurial learning, the development of entrepreneurial capabilities that are used to unlock value for both current and future use, is critical to entrepreneurial success because it supports business growth, renewal and performance (Nordic Innovation Centre, 2005). An understanding of how entrepreneurs learn is crucial to the enactment and implementation of essential entrepreneurship development interventions.

Though scholars have not yet developed a grounded theory of entrepreneurial learning, quite 
a number of studies have uncovered a lot about the entrepreneurial learning process. For instances, it is confirmed that pure formal education environment may not lead to successful entrepreneurial learning. Formal education can provide cultural awareness, knowledge and skills for entrepreneurship but the "art" of entrepreneurial practice is learnt experientially in business rather than in the educational environment (Akola \& Heinonen, 2006; Rae, 2005). Therefore, as Rae (2005) asserts, entrepreneurial learning must be explored as a contextual and active process rather than a purely educational process because entrepreneurial learning is more than a cognitive phenomenon. In addition to the effects of the context within which it takes place, entrepreneurial learning is also affected by the factors inherent in the individual entrepreneur resulting into different learning outcomes for different individuals even when the contexts are similar (Akola \& Heinonen, 2006). Intensified research that leads to harmonization of the meaning of entrepreneurial learning concept and a variety of contextualised results is necessary for the full understanding and development of entrepreneurial learning as a field of study.

Researchers have isolated factors that seem to facilitate entrepreneurial learning. Key among these factors is development of capabilities early in the career; forming a base on which entrepreneurial learning takes place (Kulmala \& Suoranta, 2005; Sandra, 1993). Entrepreneurs whose businesses grow have been found to develop a set of capabilities during earlier parts of their careers, in which they are highly confident and around which they build their careers (Sandra, 1993). Entrepreneurial qualities and capabilities can be developed through training at an early age (van der Kuip \& Verheul, 2003) or even through socialisation process.

Another crucial factor is a learning mind-set that favours exploration which, coupled with a breadth in functional work experience, facilitates generation of new business ideas (Gabrielsson \& Politis, 2012), a necessity in competitive business environment. Years of education and work experience, industry-specific experience and self-employment experience significantly improves the chance of survival in new businesses, implying an ability to learn the tactics of navigating the uncertain world of business through learning from decisions made, mistakes, experiences and networks (Kulmala \& Suoranta, 2005). Experience-based knowledge is thus a valuable asset in identification of appropriate resources and resource acquisition (Urban, van Vuuren, \& Barreira, 2008). Experiences that provide good entrepreneurial lessons are not necessarily positive. Learning from failure can be transformational (He, Tsay, \& Lee, 2011) providing a myriad of sources of information on what should be avoided, what should be strengthened as well as information on weaknesses and limitations to work on.

Another very important factor influencing entrepreneurial learning is self-efficacy. This is a person's belief in his or her capability to perform a particular task and is based upon past experience and anticipation of future obstacles (Mueller \& Dato-on, 2008; Wang, Prieto, \& Hinrichs, 2010). Because it affects one's beliefs about whether or not specific goals are attainable, if self-efficacy is low, an individual will not act, even if there is a perceived social approval for that behaviour (Mueller \& Dato-on, 2008) thus affecting the entrepreneurial learning ability of the individual. The good news is that a supportive environment promotes 
the development of entrepreneurial self-efficacy (Wang, Prieto, \& Hinrichs, 2010). Entrepreneurial self-efficacy has generally been found to be stronger in male entrepreneurs than in female entrepreneurs (Mueller \& Dato-on, 2008).

Female entrepreneurship is attracting renewed research attention as policy makers especially in developing nations come to the realization that women are an economic force that cannot be ignored (Organization for Economic Cooperation and Development (OECD), 2004). Women's involvement in entrepreneurship is applauded as a necessary precursor to economic growth of nations (Richardson, Howarth, \& Finnegan, 2004). However, women-owned businesses account for only 25 to 33 per cent of all global businesses (Kiraka, Kobia, \& Katwalo, 2013). Many factors have been blamed for this under-representation of women among business owners among them being socialisation and lack of motivation when considering entrepreneurship as a career choice (Mueller \& Dato-On, 2008).

Motivation to become an entrepreneur stems from either positive factors that "pull" individuals to entrepreneurship or negative situational factors that "push" individuals to engage in entrepreneurial activities. "Pull" motivations are positive attractions to entrepreneurship such as seeking independence, self-fulfilment and social development possibilities while "push" motivations are negative situational factors arising from a dissatisfaction with the current state such as job dissatisfaction, difficulty finding employment, insufficient salary or inflexible work schedules (Jyoti, Sharma, \& Kumari, 2011; Segal, Borgia, \& Schoenfeld, 2005; Verheul, Thurik, Hessels, \& Zwan, 2010). Though studies addressing entrepreneurial motivation factors for women in developing countries are scarce, Jyoti, Sharma and Kumari (2011) studied how these factors relate to entrepreneurial orientation and satisfaction of women entrepreneurs in India. They found out that though both "pull" and "push" factors affect entrepreneurial orientation, the quantum of influence exerted by "pull” factors is more than that exerted by "push" factors pointing to motivation being a distinguishing factor in performance of businesses (Verheul, Thurik, Hessels, \& Zwan, 2010). Further, necessity entrepreneurship is more prevalent among female entrepreneurs than male entrepreneurs (Pines, Lener, \& Schwartz, 2010) implying a low entry level due to lack of necessary preparation, a phenomenon associated with necessity entrepreneurship.

How then do female entrepreneurs learn to be entrepreneurial? Social networks are an important source of information and knowledge for entrepreneurs that would, over time, remedy the lack of initial preparation associated with necessity entrepreneurship. No doubt, networks formed by female entrepreneurs have a positive effect on their businesses, however, women's networks are generally restricted to family, workmates and friends, and they tend to be smaller and less varied than men's networks with women, in most cases, excluded from male close networks (Estrin \& Mickiewicz, 2009; Fenwick, undated; Li-Min, Chun-Chu, Chien-Min, \& Hui-Ching, 2012). This coupled with women's restricted mobility due to their responsibilities as wives and mothers renders women networks less effective in meeting their needs (Odero-Wanga, Ali-Olubandwa, \& Mulu-Mutuku, 2010; Richardson \& Macharia, 1998). Because women tend to network on a local basis, they are restricted to accessing only locally available resources and their businesses to local markets which greatly reduces their competitiveness and entrepreneurial learning capability (Richardson \& Macharia, 1998). 
In Kenya, a gender disparity has been noted in the size of enterprises. Women-owned enterprises tend to be generally smaller than enterprises owned by men (Stevenson \& St-Onge, 2005) pointing to differential entrepreneurial learning processes among other factors. Further, female entrepreneurs in Kenya are faced with quite different challenges as compared to their male counterparts. For instance, Kenyan female entrepreneurs have low levels of education compared to their male counterparts; are in need of business knowledge and skills yet they cannot afford business development services; and are affected strongly by patriarchal structures especially the role of husbands (Nyang'au, 2002; Stevenson, \& St-Onge, 2005). Yet, with all these challenges, some women, albeit a few, still own enterprises that grow and contribute towards wealth and employment creation. An understanding of women entrepreneurial learning process is necessary for facilitation in designing effective interventions for promotion of female entrepreneurship because interventions that work for men may not work for women.

In line with the realized importance of inclusion of women in economic development (Organization for Economic Cooperation and Development (OECD), 2004), supporting female entrepreneurship is an option the Government of Kenya has taken seriously. Through the then Ministry of Gender, Children and Social Development, the Government of Kenya established the Women Enterprise Fund in 2007, a semi-autonomous governmental agency whose mandate is to provide accessible and affordable credit to support women in starting and/or expanding businesses for wealth and employment creation. The Fund also provides other business support services mainly capacity building, marketing, promotion of linkages and infrastructure support (Women Enterprise Fund, 2009).

In spite of these efforts, a majority of women's enterprises in Kenya remain small, showing no signs of growth with most exiting the market at early ages (Odero-Wanga, Ali-Olubandwa, \& Mulu-Mutuku, 2010). Unless challenges to female entrepreneurship are mitigated, the full benefits of the government's effort may not be realized. Women's entrepreneurial learning process and hindrances to it would therefore need to be understood before women micro-entrepreneurs could be assisted to exploit their full potential in the business arena. This study sought to determine how women learn to be entrepreneurial and to establish hindrances to female entrepreneurial learning process.

\section{Methodology}

\subsection{Study Area}

This paper reports findings of a survey conducted on a hundred and six (106) female micro-entrepreneurs in the dairy processing industry in Nakuru, Nairobi and Kiambu Districts of Kenya. The three districts chosen for this study together constituted over $80 \%$ of the entire registered dairy processing enterprises in Kenya. Nakuru District is located within the Great Rift Valley with major economic activities being agriculture, manufacturing, tourism and commerce. Dairy farming is a key economic activity and provides the inputs for various milk processing plants as well as milk enterprises in the district (Odero-Wanga, Mulu-Mutuku, \& Ali-Olubandwa, 2013). 
Nairobi, the capital city of Kenya, is the most populous city in East Africa with a big proportion of its population earning a living through informal economic activities. The large population provides a large market for milk and dairy products (Odero-Wanga, Mulu-Mutuku, \& Ali-Olubandwa, 2013). Kiambu District is adjacent to Nairobi and has a population of 914,000 that is predominantly rural. The major economic activity in the district is agriculture with the main activities being dairy production, poultry keeping, crop production and pig farming. Nairobi provides the main market for agricultural produce from Kiambu District.

The dairy sector was chosen for this study because dairying is recognized as an effective tool for poverty reduction and sustainable livelihood by governments of developing countries (Staal et al., 1998). Further, it is one of the fast growing manufacturing sectors that absorbs many women in Kenya and has a great potential in creating wealth and employment for the poor.

\subsection{Study Population and Sample Selection}

The participants of the study were drawn from a population of women entrepreneurs owning microenterprises within the dairy industry in Nakuru, Nairobi and Kiambu Districts of Kenya. The sample consisted of 106 women entrepreneurs drawn from a sampling frame compiled using information obtained from the Kenya Dairy Board's Nairobi and Nakuru stations. This is a governmental organization that regulates the operations of milk and milk products businesses in the country. It has stations all over Kenya, some covering operations across many districts in the country. For instance, the Nairobi station covered, among other districts, Nairobi and Kiambu Districts whereas the Nakuru station covered Nakuru District. Stratified and simple random sampling procedures were used to draw the sample. Further, purposive and snowball sampling methods were used later when, during participants' identification, it was discovered that several of the registered enterprises had closed down and others had been started, a majority of which had not registered with the Kenya Dairy Board.

\subsection{Data Collection and Analysis Procedures}

Data were collected through semi-structured interviews at the site of the enterprises so that data could be enriched by direct observations of the entrepreneur's behaviour. Specifically, the observations focused on interpersonal relations between the entrepreneurs and their customers, enterprise set up and day-to-day management of resources. The collected data were analyzed using frequencies and percentages.

\section{Results and Discussion}

\subsection{Education Level of the Respondents}

Surprisingly, majority of the respondents (75\%) had secondary school education and above. Only a small proportion (2.4\%) had no formal education at all. These are high levels of education by Kenyan standards. Probably these high levels of education witnessed among the respondents could have been necessitated by the technology-intensity of the dairy industry, which may not be the case in less technology-intensive industries. Almost a third of the respondents had tertiary education of which $47.8 \%$ were trained either in dairy technology or 


\section{Macrothink}

Case Studies in Business and Management

ISSN 2333-3324

2015, Vol. 2, No. 1

in business-related areas like business management, sales and marketing. The rest were trained in business-unrelated fields like secretarial studies, nursing, education and social work. Table 1 indicates the education levels of the respondents.

Table 1. Respondents' level of education

\begin{tabular}{ll}
\hline Level of education & Percent (\%) \\
\hline No formal education & 2.4 \\
Primary education & 22.6 \\
Secondary education & 47.6 \\
Tertiary education & 27.4 \\
\hline
\end{tabular}

\subsection{Characteristics of the Studied Female-Owned Enterprises}

Many of the enterprises studied were young with $73.2 \%$ of them being three years and below and only $5.4 \%$ being 10 years and above as indicated in Figure 1. This supports Feinleib (2012) assertion that many small businesses fail within their first three years of exixtence.

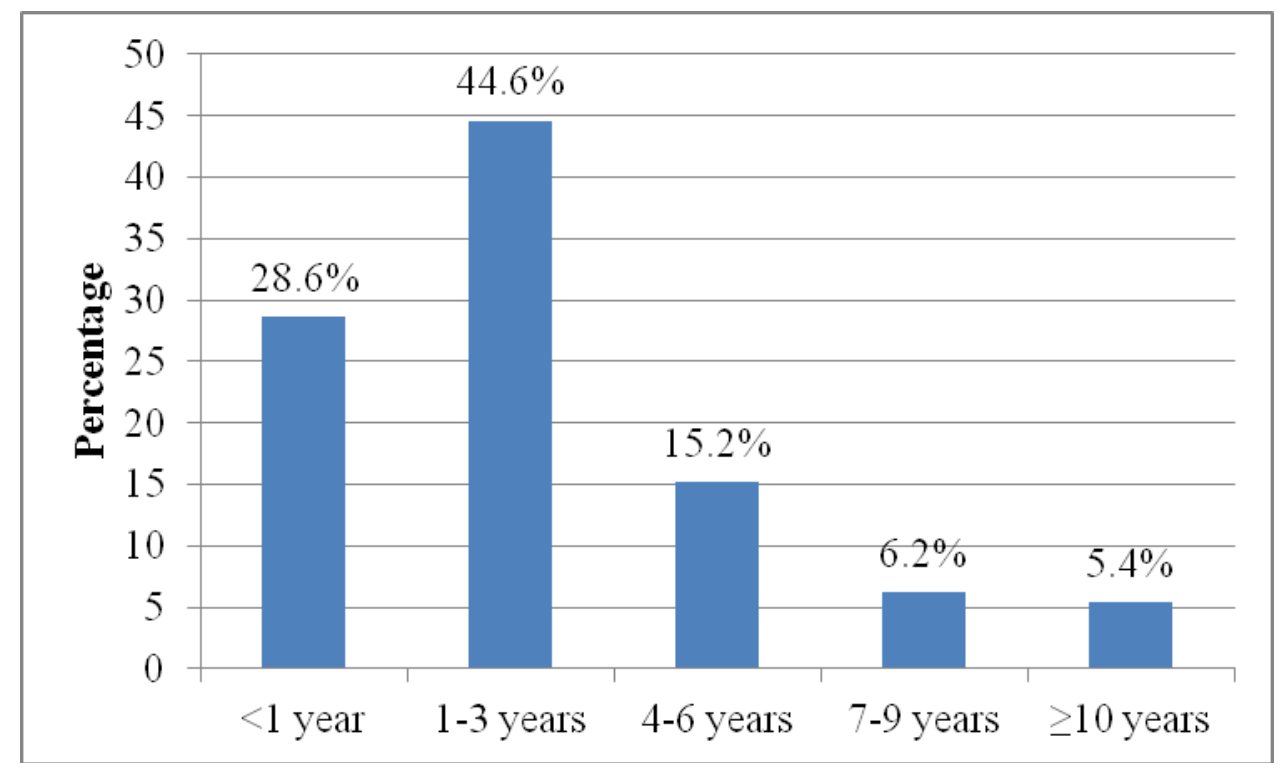

Figure 1. Age of studied enterprises

Three types of business ownership were identified as shown in Table 2. Regional differences were noted in terms of business ownership with all partnerships being recorded in Nakuru and none in Nairobi and Kiambu. Majority (67.7\%) of the enterprises in Nairobi were family owned while majority (66.7\%) in Kiambu were sole proprietorships, a pointer to economic empowerment of women in this district. Nakuru had a representation of all three types of ownership. 
Table 2. Types of business ownership

\begin{tabular}{ll}
\hline & Percent (\%) \\
\hline Family business & 48.2 \\
Sole proprietorship & 45.5 \\
Partnership & 6.3 \\
\hline
\end{tabular}

A further analysis on the products sold by the enterprises revealed six types of products with almost all enterprises (99.1\%) dealing with fresh milk and very few (0.9\%) selling butter as illustrated in Table 3.

Table 3. Products sold by studied enterprises

\begin{tabular}{ll}
\hline & Percent (\%) \\
\hline Fresh milk & 99.1 \\
Yoghurt & 36.1 \\
Maziwa mala (sour milk) & 88.0 \\
Ice cream & 3.7 \\
Ghee & 2.8 \\
Butter & 0.9 \\
\hline
\end{tabular}

\subsection{Motivation to Start Enterprise}

Individuals engage in entrepreneurial activities for various reasons which could be categorised into two: positive factors that 'pull' people towards entrepreneurial activities and negative situational factors that 'push' people into entrepreneurship (Verheul, Thurik, Hessels, \& Zwan, 2010). Entrepreneurial intentions to start a business and the decisions that occur before the start-up shape the subsequent goals, strategies, and structure of the new business (Ismail, Shamsudin, \& Chowdhury, 2012) consequently affect the entrepreneurial learning context.

Several factors motivated the entrepreneurs to start dairy enterprises with majority $(71.0 \%)$ being motivated by the need to provide for their families economically (see Figure 2). This group consisted of women who were retrenched from previous employment or who could not get salaried employment and therefore could not provide for their families economically. Others were motivated by lack of market for raw milk after the collapse of Kenya Co-operative Creameries (KCC) which had been the major buyer and processor of milk in the country for decades. Some entrepreneurs in this group owned dairy cows but did not have a market for the milk. They therefore decided to start dairy enterprises to sell their milk and provide an outlet for milk from friends.

Categorising these motivating factors into necessity and opportunity-driven entrepreneurship, it becomes apparent that a vast majority (72.8\%) of the female entrepreneurs were 'pushed' to entrepreneurial activities by negative situational factors in their lives. They had to earn a 
living but lacked employment opportunities and still others had to accommodate their reproductive roles within their work schedules. Dairy enterprises that could be operated within homes or in the home vicinity became the best option.

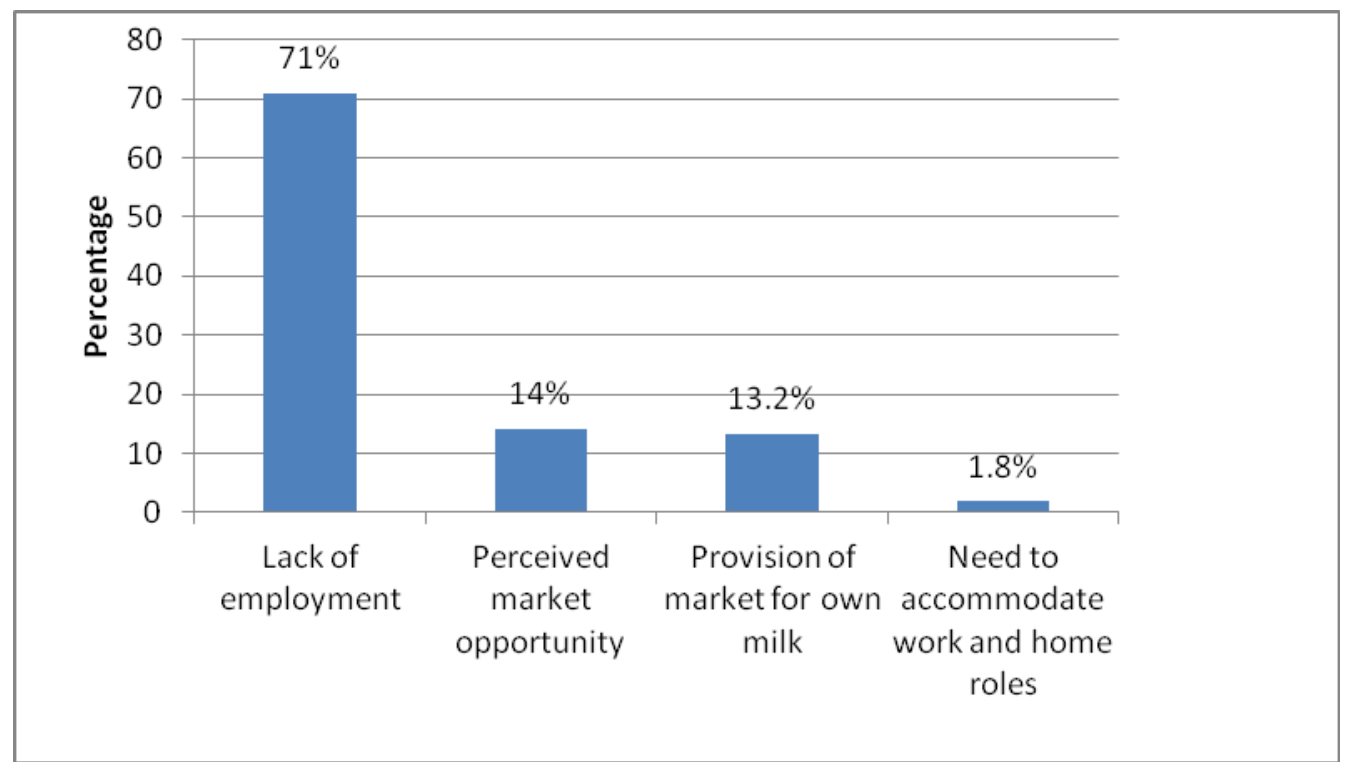

Figure 2. Factors motivating entrepreneurs to start dairy enterprises

\subsection{Source of Skills and Knowledge in Entrepreneurship}

When asked how they learnt the skills and knowledge they use in running their enterprises, majority (76.9\%) of the women learnt the skills 'on-the job' through trial and error. Only $5.5 \%$ of the respondents had training in business-related fields such as marketing and business management before starting their enterprises. Another $17.6 \%$ had learnt some business skills from previous employment.

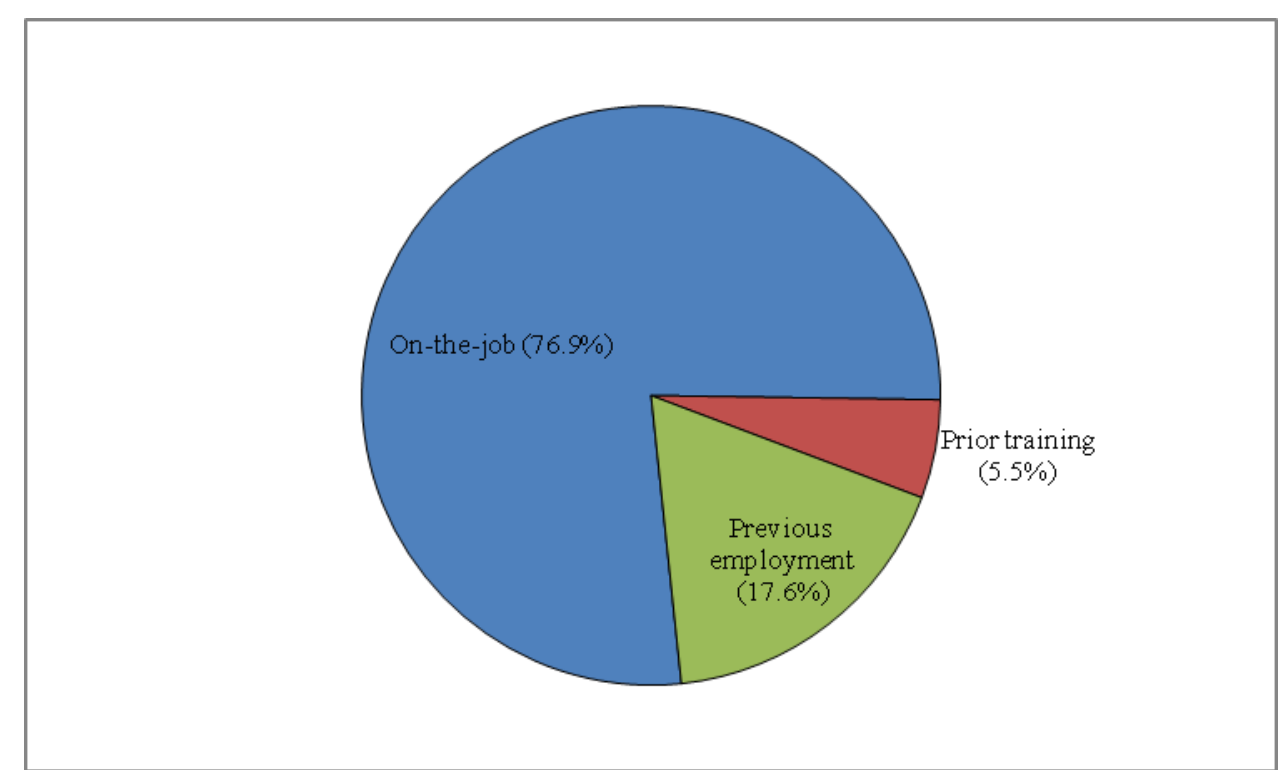

Figure 3. Sources of skills and knowledge in entrepreneurship 
As for ways of upgrading knowledge on management of enterprises and the processing of products, most of the entrepreneurs used family and friends, informal self-help group meetings and consultants. Though a number of them used more than one source, it is evident that social contacts and relations were important sources of business knowledge and skills accounting for $68.7 \%$.

Table 4. Methods of upgrading knowledge

\begin{tabular}{ll}
\hline & Percent (\%) \\
\hline Family and friends & 39.1 \\
Self help group & 29.6 \\
Consultants & 16.5 \\
Reading & 6.1 \\
Shows \& exhibitions & 0.9 \\
Competitors \& customers & 16.5 \\
\hline
\end{tabular}

\subsection{Entrepreneurial Learning Networks}

An attempt was made to establish the types of networks used by female entrepreneurs for learning purposes. Four types of networks were identified;

- Informal self-help groups,

- Suppliers of milk and customers,

- Experts in dairy processing, for example professionals from universities and from Kenya Dairy Board, and

- A network of relatives and friends who had knowledge in dairy processing and business management.

Among these networks, social contacts and relations, such as friends, husbands, parents, brothers and sisters, were the most important sources of knowledge and skills with a sizable proportion (18.5\%) relying solely on husbands to provide business knowledge and skills. This was more of a passive rather than active learning process, where the husbands came home with a new skill and passed it on to their wives. This is in line with other studies that have revealed that women rely more on spouses for information and support than on outside advisors such as bankers and lawyers (Fenwick, undated).

Rarely did we have respondents reporting cases of active search for business information, a necessity in growing businesses (see Rae, 1999). Half (50\%) of the respondents cited lack of knowledge on sources of information as the reason for passivity in entrepreneurial information search. Others cited lack of time while others cited high costs of doing so. These are genuine reasons affecting, not only women in the dairy industry, but women entrepreneurs in general. Most women entrepreneurs are ignorant of sources of assistance, a problem aggravated by lack of strong and diverse networks. Further, due to multiple roles as mothers 
and wives, women are left with little time for business and socialization (Richardson \& Macharia, 1998) affecting negatively their entrepreneurial learning process.

\subsection{Entrepreneurial Self-Efficacy}

Benefits from learning networks are maximised through a strong belief in one's ability to achieve what they set out to achieve. In the context of entrepreneurship, this belief is referred to as entrepreneurial self efficacy (Mueller \& Dato-on, 2008; Wang, Prieto, \& Hinrichs, 2010). Lack of confidence and self belief has negative effects on an individual's achievement motivation (Mueller \& Dato-on, 2008; Vyakarnam, 1998) and consequently on the entrepreneurial learning process. A big proportion of the respondents studied did not portray confidence in their ability to achieve what they set out to achieve. Majority (70.8\%) of the female entrepreneurs believed that the success of their enterprises, in terms of enterprise growth, was mainly determined by factors beyond their control and no matter what they did they would never succeed. This was an indication of low levels of entrepreneurial self efficacy that impacted negatively on entrepreneurial learning ability. Some of the factors blamed for lack of success were poor legislation, climatic conditions that affect the supply of milk, vending of milk by unlicensed individuals thus creating unfair competition and unscrupulous local authority law enforcers.

Half (50\%) of the respondents uttered statements that reflected a state of discouragement and despair. Examples of such statements were;

"The government needs to do something to help us otherwise; we will have to close down".

"I am thinking of closing down."

“This business cannot give me enough profit to support my family”.

"A few years ago I used to operate two bank accounts but now I cannot even operate one",

\section{Conclusion}

Entrepreneurship development is one of the main poverty reduction and wealth creation strategies adopted by the Government of Kenya as the government envisions a transformed, newly industrialising, middle-income Kenya, providing a high quality life to all her citizens by the year 2030 (Government of the Republic of Kenya, 2007). Special attention has been given to, among others, investment in unemployed youth and women through devolvement of funds for enterprise development with the hope of reducing national poverty levels and creating job opportunities (Government of the Republic of Kenya, 2007). Therefore understanding the entrepreneurial learning process of women entrepreneurs contributes greatly in the enactment of effective policies and strategies in support of the country's Vision 2030 initiatives. Women, the majority in Kenya, form a great economic force which, if adequately tapped, could move the country to great heights of economic prosperity. With women empowerment, more and more women are participating in entrepreneurial activities though most of their enterprises remain small compared to those owned by their male 
counterparts.

The findings of this study reveal that female entrepreneurs learn to be entrepreneurial majorly through two processes: on-the-job on their own through trial and error methods and through social networks of friends and relatives. Social networks are also important in upgrading entrepreneurial information, knowledge and skills. The challenge afforded by these two methods is that of not interacting with theoretical concepts that are necessary in understanding the scientific basis of business processes. This interferes with the ability of making right choices and decisions in the business arena.

With a large proportion of female entrepreneurs in this study having high levels of education, entrepreneurial learning is expected to be easier and faster because of the exposure afforded by education. However, female entrepreneurship is dominantly necessity entrepreneurship, preceded by little preparation. Consequently, majority start entrepreneurial activities without prior knowledge adversely affecting their entrepreneurial learning process due to lack of a good base upon which entrepreneurial learning takes place (Kulmala \& Suoranta, 2005). The Government of Kenya may need to adopt a strategy that prepares the general female population for entrepreneurship. Since primary and secondary school education plays the most important role in changing the overall culture towards entrepreneurship (International Labour Organisation, 2001), an entrepreneurship development curriculum, weaved through the entire school syllabus may help in entrenching an enterprising culture among women. In addition, exposure of school girls to role models and an opportunity to experience entrepreneurship activities firsthand may strengthen motivation to choose entrepreneurship as a career.

While sources of business information and assistance exist, majority of female entrepreneurs are not aware of their existence. Business networks are an important source of business knowledge but due to the nature of women networks (local-based, small in coverage and weak in ties) and the restricted mobility of female entrepreneurs, female entrepreneurs' networks do not assist much. Strong networks, especially with providers of assistance and with others in the field of business would help create the necessary awareness and confidence on the available sources of assistance.

The observed low levels of entrepreneurial self efficacy portrayed through lack of confidence and self belief does not auger well with entrepreneurial learning and enterprise growth. Bearing in mind that most women-owned enterprises continue to remain small, even in the developed world (Tempest, 1997), concerted efforts need to be directed towards developing female entrepreneurship and in particular, female entrepreneurial learning process. Interventions that boost female entrepreneurial self efficacy may go a long way in boosting female entrepreneurial learning process and therefore developing female entrepreneurship.

\section{Acknowledgement}

We are grateful to The OFEL 2014 Conference on Governance, Management and Entrepreneurship paper reviewers for their comments on an earlier version of this paper. 


\section{References}

Akola, E., \& Heinonen, J. (2006). Does training of Entrepreneurs support entrepreneurial learning: A study of training programmes for existing and potential entrepreneurs in seven European countries. Research Paper. International Council for Small Business (ICSB) 51st World Conference in Melbourne 18-21 June 2006.

Estrin, S., \& Mickiewicz, T. (2009). Do Institutions Have a Greater Effect on Female Entrepreneurs? IZA Discussion Paper No. 457, The Institute for the Study of Labor (IZA).

Feinleib, D. (2012). Why Startups Fail: And How Yours Can Succeed. New York: Apress.

Fenwick, T. (undated). Women entrepreneurs: A critical review of the literature. Retrieved October 8, 2002, from www.ualberta.ca/ tfenwick/ext/pubs/leaders.htm

Gabrielsson, J., \& Polotos, D. (2012). Work experience and the generation of new business ideas among entrepreneurs: An integrated learning framework. International Journal of Entrepreneurial Behaviour and Research, 18(1), 48-74. http://dx.doi.org/10.1108/13552551211201376

Government of the Republic of Kenya. (2007). Kenya Vision 2030. Nairobi: Government Printer.

He, F., Tsay, H. H., \& Lee, J. H. (2011). Failure is the Mother of Success... Only When Learning Occurs: A Theoretical Framework of Entrepreneurial Learning from Failure. Retrieved from http://sbaer.uca.edu/research/icsb/2011/673.pdf

Institute of Economic Affairs/Society for International Development. (2001). Kenya at the crossroads: Scenarios for our future. Nairobi: Institute of Economic Affairs.

International Labour Organisation. (2001). Overcoming constraints to entrepreneurship and business growth. Geneva: ILO.

Ismail, H. C., Shamsudin, F. M., \& Chowdhury, M. S. (2012). An Exploratory Study of Motivational Factors on Women Entrepreneurship Venturing in Malaysia. Business and Economic Research, 2(1), 1-13.

Jyoti, J., Sharma, J., \& Kumari, A. (2011). Factors affecting orientation and satisfaction of women entrepreneurs in rural India. Annals of Innovation and Entrepreneurship, 2(1). http://dx.doi.org/10.3402/aie.v2i1.5813

Kiraka, R. N., Kobia, M., \& Katwalo, A. M. (2013). Micro, Small and Medium Enterprises Growth and Innovation in Kenya: A case study on the women Enterprise Fund. IDRC, Dakar. Retrieved June 16, 2013, from www.trustafrica.org/icbe

Kulmala, K., \& Suoranta, M. (2005). Learning in the Context of Entrepreneurial Marketing. Frontiers of E-Business Research.

Li-Min, C., Chun-Chu, L., Chien-Min, H., \& Hui-Ching, T. (2012). An Evaluation Model of Female Entrepreneurship in the Service Industry-Human Capital, Social Capital and 
Opportunity Recognition Perspective. International Research Journal of Finance and Economics, 85, 55-67.

Mueller, S. L., \& Dato-on, M. C. (2008). Gender-role orientation as a determinant of entrepreneurial self-efficacy. Journal of Developmental Entrepreneurship, 13(1), 3-20.

Nyang'au, I. M. (2002). The role of informal sector in Rural Development: A case study of carpentry and tailoring in Gucha District, Kenya. Swedish University of Agricultural Sciences Department of Rural Development Studies Uppsala.

Odero-Wanga, D., Ali-Olubandwa, A., \& Mulu-Mutuku, M. (2010). Women in milk micro-enterprises in Kenya: Challenges and Opportunities. Journal of business administration and management, 5(3), 150-156.

Odero-Wanga, D., Mulu-Mutuku, M., \& Ali-Olubandwa, A. (2013). Overcoming the odds: Strategies used by women entrepreneurs in milk microenterprises in Kenya. American Journal of Human Ecology, 2(2), 60-66.

Ondiege, P. (1995). Informal sector development models and assistance programmes in Kenya. University of Nairobi: Housing \& Building Research Institute.

Organisation for Economic Co-operation and Development. (2004). Women's entrepreneurship: issues and policies. In proceedings of the $2^{\text {nd }}$ OECD Conference of Ministers Responsible for Small and Medium-sized Enterprises (SMEs), Istanbul, Turkey.

Palmer, R. (2008). Skills and productivity in the informal economy. Employment Working Paper No. 5, International Labour Organization.

Richardson, P., \& Macharia, R. (1998). Gender Issues affecting Growth. Retrieved June 5, 2003, from http://www.nbs.ntu.ac.uk/DEPTS/CGB/CONFER/1998-03.a/Richardson.html

Richardson, P., Howarth, R., \& Finnegan, G. (2004). The Challenges of Growing Small Businesses: Insights from Women Entrepreneurs in Africa. SEED Working Paper No. 47. Geneva: International Labour Office.

Sandra, K. (1993). Women and entrepreneurship. Retrieved August 10, 2002, from http://www.celcee.edu/abstracts/c19960381.html

Staal, A. J., Chege, L., Kenyanjui, M., Kimari, A., Lukuyu, B., Njumbi, D., ... Wambugu, M. (1998). Characterisation of dairy systems supplying the Nairobi milk market: A pilot survey of Kiambu District for the identification of target groups of producers. Kenya Agricultural Research Institute/Ministry of Agriculture/International Livestock Research Institute collaborative research project report, Nairobi, Kenya.

Stevenson, L., \& St. Onge, A. (2005). Support for growth-oriented women entrepreneurs in Kenya. International Labour Organization: Geneva.

Stoner, J., Freeman, R., \& Gilbert, D. (1995). Management. Prentice Hall Inc: Englewood Cliffs, New Jersey. 
Tempest, C. (1997). Entrepreneurial women in the United States. Retrieved October 8, 2002, from http://www.celcee.educ/publications/digest/Dig97-2.html

Urban, B., van Vuuren, J., \& Barreira, J. D. (2008). High-growth entrepreneurs: The relevance of business knowledge and work experience on venture success. Journal of Contemporary Management, 5, 58-71.

Van der Kuip, I., \& Verheul, I. (2003). Early Development of Entrepreneurial Qualities: the Role of Initial Education. Scientific Analysis of Entrepreneurship and SMEs, paper N200311. Retrieved from http://www.entrepreneurship-sme.eu/pdf-ez/N200311.pdf

Verheul, I., Thurik, R., Hessels, J., \& Zwan, P. (2010). Factors Influencing the Entrepreneurial Engagement of Opportunity and Necessity Entrepreneurs. Scientific Analysis of Entrepreneurship and SMEs. Retrieved from www.entrepreneurship-sme.eu

Vyakarnam, D. S. (1998). Entrepreneurship and Growth: The real benefits of development. Retrieved June 5, 2003, from http://www.nbs.ntu.ac.uk/DEPTS/CGB/CONFER/1998-03.a/Vyakarnam.doc

Wang, C. L. (2008). Entrepreneurial orientation, learning orientation, and firm performance. Entrepreneurship Theory and Practice, 32(4), 635-656.

Wang, C. L., \& Rafiq, M. (2009). Organizational diversity and shared vision: resolving the paradox of exploratory and exploitative learning. European Journal of Innovation Management, 12(1), 86-101.

Wang, L., Prieto, L., \& Hinrichs, K. T. (2010). Direct and indirect effects of Individual and environmental factors on motivation for self-employment. Journal of Developmental Entrepreneurship, 15(4), 481-502. http://dx.doi.org/10.1142/S1084946710001671

Women Enterprise Fund. (2009). Women Enterprise Fund Strategy Plan 2009-2012. Ministry of Gender, Children and Social Development, Nairobi.

\section{Copyright Disclaimer}

Copyright for this article is retained by the author(s), with first publication rights granted to the journal.

This is an open-access article distributed under the terms and conditions of the Creative Commons Attribution license (http://creativecommons.org/licenses/by/3.0/). 